\title{
RETHINKING MOTHERHOOD AND MOTHERLY LOVE IN TONI MORRISON'S SULA AND GLORIA NAYLOR'S THE WOMEN OF BREWSTER PLACE
}

\author{
Ane Caroline Ribeiro* \\ Universidade Federal de Minas Gerais \\ Belo Horizonte, MG, BR \\ José de Paiva dos Santos ${ }^{* *}$ \\ Universidade Federal de Minas Gerais \\ Belo Horizonte, MG, BR
}

\begin{abstract}
This article examines how the novels Sula, by Toni Morrison, and The Women of Brewster Place, by Gloria Naylor, deconstruct long-held controlling images of black women, particularly the matriarch. The characters Eva Peace in Sula and Mattie Michael in The Women of Brewster Place, among others, provide great illustrations of black women who have rejected many of the places and stereotypes reserved for them in society, consequently deconstructing controlling images white society has imposed on them. These novels highlight black women's plural roles in society, thereby opening possibilities for a liberating experience of black womanhood.
\end{abstract}

Keywords: Controlling Images; Black Women; Matriarch; U.S. Fiction

\section{Introduction}

The plight of black women in the United States history has been widely discussed, the main focus being the struggles they have had to face since they first set foot on American shores in the seventeenth century as chattel slaves (West 294). If in the past they had to bear the sexual and economic exploitation of white men, as well as the domestic, physical and psychological abuse of white women, along with the pain of seeing their offspring killed, beaten or sold to other even more cruel masters, today most black women have to deal with the frustrations of emasculated, disenfranchised husbands, low-paying jobs, work overload, single parenting, and gender and race discrimination. As Alice Walker has put it, "black women are called, in the folklore that so aptly identifies one's status in society, 'the mule of the world' because [they] have been handed the burdens that everyone else - everyone else - refused to carry" (229). Hardly anyone contests that the history of black women has been a trajectory fraught with hostility, deprivation, mistreatment, and unrecognition of their talents and creative spirit. One direct consequence of this ideology bell hooks has termed "white-supremacist capitalist patriarchy" (8) has been the production of a series of types or controlling images regarding the black female subject, aiming to categorize black women's experience according to the roles they are expected to play in society. According to Rasul Mowatt and Bryana French, black women's bodies are only visible through stereotypical images with the purpose of ridiculing them, as the case of the body of Sara Baartman, which was exposed naked for many decades in London during the nineteenth century, and became

\footnotetext{
${ }^{*}$ Mestre em Literaturas de Língua Inglesa, área de pesquisa Literatura, História e Memória Cultural, pela Universidade Federal de Minas Gerais (2016). Licenciada em Letras/ Inglês (2011), Bacharel em Inglês (Estudos Literários) (2014), pela mesma instituição. Seu endereço de email é anecarol.faria@gmail.com

${ }^{* *}$ Doutor em Literatura Comparada pela Purdue University (2001), EUA. Professor Associado de Literaturas de Língua Inglesa na Universidade Federal de Minas Gerais. Seu endereço de email é josedepaivasantos@gmail.com
} 
known as Hottentot Venus (645). Moreover, according to Sander Gilman, black images have been connected to illicit sexual activity and "primitive" sexuality since the middle ages, and towards the nineteenth century it started to symbolize sexually transmitted diseases such as syphilis (228).

One image in particular, which became very popular in post-bellum US, was that of the matriarch. At that time, due to the hardships black men faced to find decent jobs, many black women were forced to assume the role of the family provider, having to conciliate domestic responsibilities and a job outside the home. The image of the matriarch came into existence, was in fact officially constructed, in Daniel Moynihan's report "The Negro Family - the Case for National Action," published in 1965. As a government worker, he was interested in studying the disparities in income, education, and health between black and white families. In his report, he blamed most of the social ills affecting the black population on the lack of a strong father figure in the home, that is, the lack of a patriarchal structure modelling that of white families. In addition, because black mothers were absent most of the day, Moynihan claimed, their children were left uncared for and were more likely to drop out of school, join gangs, get pregnant earlier, and become involved in criminal activities (2527). The image of the matriarch became thus associated with black women who were too assertive, independent and used to bossing their husbands around. The report also claimed that their unfeminine posture and overly aggressive behavior scared men away or even potential husbands, contributing thus to the large number of single-parent families run by black women. Therefore, as Patricia H. Collins explains, black matriarchs started to be blamed for their husbands' emasculation, their children's failures at school, and their getting in trouble with the law (74-77).

Despite the educational and professional progress black women have achieved over the years, the image of the matriarch still remains in the collective imaginary of whites and blacks alike. Black feminist scholars remark that many black women still blame themselves when their children fail at school and get in trouble with the law; if only they were less assertive and more feminine, they would find a male partner to help them or would have kept their respective husbands (Collins 77). The problem with this view, scholars point out, is that it fails to account for the socio-political processes that have left both black women and men excluded from the system. Stereotyping also helps to mask a host of racist policies which employ "images of bad Black mothers to explain Black economic disadvantage," thereby "link[ing] gender ideology to explanations for extreme distributions of wealth that characterize American capitalism" (Collins 76).

Creative writers, especially in the second half of the twentieth century, used literature as a tool to expose and critique the ideological mechanisms that have reduced black women's experience to such stereotypes. Therefore, the purpose of this essay is to discuss how black literature has taken to task these controlling images by problematizing and deconstructing long-held stereotypes of black women. As such, it will examine Toni Morrison's novel Sula and Gloria Naylor's The Women of Brewster Place, focusing, especially, on the textual and narrative strategies they employ to provide alternative representations of black female subjects.

\section{"I stayed alive for you": Beyond the controlling image of the matriarch}

After being abandoned by her abusive husband, Eva Peace decides to take matters into her own hands. The children needed food; no jobs were available in the Bottom community or nearby. Therefore, she leaves her children with a neighbor promising to return the next day. After an eighteen-month period of absence, Eva Peace returns, one leg missing, using crutches, and reclaims the children she left behind. No one knows exactly where and how she got the money to start building a house right after. She later informs her daughter Hannah that she stayed alive and overcame all adversities for her family's sake (Morrison, Sula 69). Similar to Eva Peace, Mattie Michael boldly faces her community and family to ensure the right to raise and protect her child, born out of wedlock. Mattie Michael ends up abandoned twice: first by her family, especially her father, who cannot deal with the fact 
that his daughter is having an illegitimate child; then by her own son Basil, who, now as an adult, gets in trouble with the law, runs away, and makes Mattie lose the house she put on bail for him. It is in the Brewster community that she eventually goes for shelter. There, she becomes a source of strength and spiritual guidance for many women in distress. These and other characters from Sula and The Women of Brewster Place, acclaimed novels by the authors Morrison and Naylor, respectively, stand out as examples of different perspectives on motherhood, thereby confronting simplistic, reductive notions concerning this typical role in women's lives. By providing more complex, variegated, well-rounded depictions of black women's experience, these novels assist thus in the deconstruction of many controlling images, in particular, the matriarch.

As previously discussed, the controlling image of the matriarch is the product of a patriarchal and racist system that overlooks the intricacies of racial and gender relations in society. It does not take into account, for instance, black women's diverse positions within the black community, their perceptions of motherhood, their heritage of racism and oppression, as well as their various forms of relationship with black men (Sewell 313). The character Eva Peace, in Sula, illustrates well some of these features and challenges, in many ways, the typical matriarch controlling image. The novel portrays Eva as a complex individual who is abandoned by her husband BoyBoy and is forced to work to make ends meet:

\begin{abstract}
After five years of a sad and disgruntled marriage BoyBoy took off. During the time they were together he was very much preoccupied with other women and not home much. $\mathrm{He}$ did whatever he could that he liked, and he liked womanizing best, drinking second, and abusing Eva third. (Morrison, Sula 32)
\end{abstract}

This passage suggests that, contrary to cultural beliefs that black women emasculate their husbands, adultery, violence, and BoyBoy's inability to provide for his family seem to be the trigger for the failure of their marriage. In Eva's case, she is abandoned not because of her domineering position in the family, but because she is treated terribly by her husband. In fact, he did "whatever he could that he liked." When BoyBoy leaves for good, all Eva is left with are "\$1.65, five eggs, three beets" and three children - three children with so pressing needs that she had to "postpone her anger for two years until she had both the time and the energy for it" (Morrison, Sula 32).

The novel does not provide evidence on why BoyBoy abandons Eva and the children. At first sight, it appears he is not mature enough to take on a family, being more interested in women and drinking than in raising children. bell hooks, in explaining family dynamics in mid-twentieth-century US, explains that "in every segregated black community in the United States there [were] adult black men married, unmarried, gay, straight, living in the households where they [did] not assert their patriarchal domination and yet live[d] fulfilled lives, where they were not sitting around worried about castration" (We 10). In other words, the white patriarchal model of the man being the main provider was not followed by all black men. The experience of slavery, emancipation, racism and white supremacy affected black men and women in a variety of ways. As hooks further explains, "many males were as uninterested in traditional sexist roles as were females, if not more so." Furthermore, "unlike white males, black males did not have an institutionalized patriarchal-influenced morality to make them feel less manly if they abandoned their families" (11). Not all black women took on the role of the emasculating matriarch, either. BoyBoy, for instance, pays Eva a visit only three years after his departure - occasion in which he shows no regrets for abandoning her: "BoyBoy didn't ask to see the children, and Eva didn't bring them into the conversation" (Morrison, Sula 36). BoyBoy does not feel he is responsible for Eva's children; he perhaps does not even feel they are his as well. Fatherhood is not an issue to BoyBoy because he does not feel it has any significance in the construction of his manhood, which, in this sense, would be constructed by other principles, such as sexuality, violence, and so forth. What the novel shows, thus, is a more complex picture of family dynamics in the black community, one in which the white patriarchal model of the man running the house 
is not the standard. He leaves Eva not because she is a controlling figure or, for that matter, a bad mother.

The same pattern is seen in Eugene from Brewster and Jude Greene from Sula. Eugene is married to Lucielia Louise Turner - mainly referred to as Ciel. Here, Eugene leaves because he cannot keep a stable job and support his family; he leaves Ciel, then, "sick, with a month-old baby" (Naylor, Brewster 91). When he comes back, eleven months later, Ciel is certain he has finally straightened up. Ciel comments, trying to convince Mattie and herself of Eugene's adjustment: "He's got a new job on the docks that pays real good, and he was just so depressed before with the new baby and no work" (Naylor, Brewster 92).

Having a job that pays well means everything to Eugene; he cannot bear the idea of being unable to support his wife and children. Not surprisingly, things soon start going wrong again, especially when he loses his job, and Ciel gets pregnant of their second child:

How in hell I'm gonna make it with no money, huh? And another brat comin' here, huh? ... I'm fuckin' sick of never getting ahead. Babies and bills, that's all you good for... With two kids and you on my back, I ain't never gonna have nothin'. (Naylor, Brewster 94)

Here, Eugene blames Ciel for his inability to succeed in life, when in fact, racism and oppression are the real culprits. Consequently, he feels isolated, emasculated and drifts away from the people who could really love him. He storms at Ciel because he cannot storm at anybody else. He cannot scream at his white boss, or at the society that would never allow him to have the things he craves for. He feels, and rightly so, that the white world oppresses him; and the only way to feel as a man is by making Ciel inferior to him. His final reaction is abandoning Ciel and Serene, their child.

In Sula, Jude Greene desires a real job - such as taking part in the construction of a bridge that would "connect Medallion to Porter's Landing, the town on the other side" (Morrison, Sula 81). Jude longs for a job that will make him proud:
Not just for the good money, more for the work itself. He wanted to swing the pick or kneel down with the string or shovel the gravel. His arms ached for something heavier than trays, for something dirtier than peelings; his feet wanted the heavy work shoes, not the thinsoled black shoes that the hotel required. More than anything he wanted the camaraderie of the road men: the lunch buckets, the hollering, the body movement that in the end produced something real, something he could point to. "I built that road," he could say ... People would walk over his sweat for years. Perhaps a sledge hammer would come crashing down on his foot, and when people asked him how come he limped, he could say, "Got that building the New Road." (Morrison, Sula 81-82)

Not having opportunities to do any other kind of work other than serving people (white people) makes Jude feel that he is less of a man; he wants a job in which he could do something that matters. Even pain would be worthy; if only he could feel he had a real job:

\footnotetext{
It was after he stood in lines for six days running and saw the gang boss pick out thin-armed white boys from the Virginia hills and the bull-necked Greeks and Italians and heard over and over, "Nothing else today. Come back tomorrow," that he got the message. (Morrison, Sula 82)
}

At this point, he understands he will not get hired because he is a black man, "remaining within the understood boundaries prescribed by the hostile White world" (Nigro 726). Work opportunity, in this sense, has a major importance in Jude's construction of manhood, and not being able to perform it puts at risk his masculinity (17). When he realizes that, because of his color, he will not achieve such a manlike position, he decides to press Nel about getting married. He feels the institution of marriage will yield him the so-desired feeling of manhood. As the narrator puts it, without Nel, Jude feels like "a waiter hanging around a kitchen like a woman" (Morrison, Sula 83). Married to her, he is a man, albeit stuck to "an unsatisfactory job out of necessity" (Morrison, Sula 83). Eventually, Jude also abandons Nel and their three children.

These two cases suggest that black women, or the matriarch figure, for that matter, are not the ones 
responsible for emasculating black men. In fact, they are unduly blamed and stereotyped for something outside their sphere of influence. hooks explains that after Moynihan's 1965 report "The Negro Family," "the discourse of emasculation shifted from white supremacy and accountability for black male oppression to blaming black women" (12). In other words, white society imposed a patriarchal model on black males but did not provide them with the opportunities to perform it. The blame had to fall somewhere, and it did fall on black women's assertive attitude. What Sula and Brewster suggest is that within the dynamics of white capitalism, black males would not be patriarchs even if black women did not have jobs.

Further analysis of Eva Peace reveals another important element challenging the black matriarch model: she does not really work outside the home. She has to come up with other means to earn money and provide for her family, firstly because her children, at the time when BoyBoy abandons them, are very young. Hannah, the oldest, is only five "and too young to take care of the baby alone" (Morrison, Sula 33). Secondly, job opportunities for black women at the time are scarce: "any housework Eva could find would keep her away from them from five thirty or earlier in the morning until dark-way past eight" (33). Other than that, there is not much she can do; additional options of jobs would probably only be prostitution (Christian 17). Returning South is a dreadful thought to Eva: "to come home dragging three young ones would have to be a step one rung before death for Eva" (Morrison, Sula 33). Thus, after a night in which her youngest child, a boy she calls Plum, almost dies of constipation, and they are all nearly starving to death, Eva leaves her children with a neighbor, promising to come back the next day. However, she only returns eighteen months later, "with two crutches, a new black pocketbook, and one leg" (Morrison, Sula 34). A check starts coming every month; Eva builds a house full of rooms and doors, where she raises her three children, and later her granddaughter, Sula. Eva's loss of her leg is a great mystery in the novel, but rumor has it that she put it under a train to collect insurance:
Fewer than nine people in the town remembered when Eva had two legs... Somebody said Eva stuck it under a train and made them pay off. Another said she sold it to a hospital for $\$ 10,000$ - at which Mr. Reed opened his eyes and asked, "Nigger gal legs goin" for $\$ 10,000$ a piece?" as though he could understand $\$ 10,000$ a pair-but for one? Morrison, Sula (30-31)

Regardless of whether any of these rumors are true or not, it is clear that Eva has found a way out of the patriarchal and racist system that denied her the means of taking proper care of her family. Although Eva had to make tough decisions to keep her children alive, including leaving them with a neighbor for a year and a half, she does not seem to be in distress. She pronounces herself happy, for she nurtures a very strong feeling for BoyBoy: hate.

Hating BoyBoy, she could get on with it, and have the safety, the thrill, the consistency of that hatred as long as she wanted or needed it to define and strengthen her or protect her from routine vulnerabilities. (Once when Hannah accused her of hating colored people, Eva said she only hated one, Hannah's father BoyBoy, and it was hating him that kept her alive and happy). (Morrison, Sula 36-37)

Contrary to the matriarch controlling image, what protects Eva from routine vulnerabilities is not her inbuilt strength, but the hate she nurtures for her exhusband. Hate keeps her alive because it protects her from emotional and mental pain; nothing but hate may give her the security she needs to carry on. Nonetheless, Eva's hate towards BoyBoy does not shut her up to other men; in fact, she keeps on appreciating manliness:

Those Peace women loved all men. It was manlove that Eva bequeathed to her daughters. Probably, people said, because there were no men in the house, no men to run it. But actually that was not true. The Peace women simply loved maleness, for its own sake. (Morrison, Sula 41)

Eva, even with one leg and already an elder woman, "had a regular flock of gentleman callers, and although she 
did not participate in the act of love, there was a good deal of teasing and pecking and laughter" (Morrison, Sula 41). Eva is particularly feminine, and in no way emasculates her callers; in fact, they liked to argue with her, once "she argued with them with such an absence of bile, such a concentration of manlove, that they felt their convictions solidified by her disagreement" (Morrison, Sula 41-42); when they were defeated in the game of checkers, it felt like wining. Her presence strengthened their ego, which opposes the belief concerning matriarchs' behavior towards men.

It is true that Eva, in many instances, seems to endorse the matriarch's image because of her domineering position in the house; she seems to be a bad mother, too, sometimes. But the story suggests also that these two positions are related to Eva's notion of what being a mother means - Eva believes that being a mother is raising one's children despite all odds and being able to empower them. For Eva, there is no distinction between loving her children and not letting them perish. According to Andrea O'Reilly, Eva's maternal love is a "preservative love" (Morrison, Sula 118). That is, "mothering for many black women, particularly among the poor, is about ensuring the physical survival of their children and those of the larger black community" (Morrison, Sula 119), but most of the time, preservative love "is not regarded as real, legitimate, or "good enough" mothering" (O'Reilly 120). In this sense, Eva Peace appears to be a bad mother, once she does not possess the traditional and acceptable motherly way of showing affection.

For instance, when her oldest daughter, and Sula's mother, Hannah, asks her if she had ever loved them, she reminds Hannah that she had done more than love them; she had kept them alive: 'you settin' here with your healthy-ass self and ax me did I love you? Them big old eyes in your head woulda been two holes full of maggots if I hadn't'" (Morrison, Sula 68). Hannah asks such a question because she is thinking of a particular type of motherly love, which probably exists only in people's imagination. "I didn't mean that, Mamma. I know you fed us and all. I was talkin' 'bout something else. Like. Like. Playin' with us. Did you ever, you know, play with us?" (Morrison, Sula 68), she explains. Playing, in this sense, represents the idea that motherhood only involves happiness and dreamlike feelings - a fantasy which diminishes the hardships a mother, especially a black single mother in a racist and sexist society, has to endure (O’Reilly 123):

\begin{abstract}
Play? Wasn't nobody playin' in 1895 ...I set in that house five days with you and Pearl and Plum and three beets, you snake-eyed ungrateful hussy... Don't that count? Ain't that love? You want me to tinkle you under the jaw and forget 'bout them sores in your mouth? Pearl was shittin' worms and I was supposed to play rang-around-the-rosie?... what you talkin' 'bout did I love you girl I stayed alive for you can't you get that through your thick head or what is that between your ears, heifer? (Morrison, Sula 68-69)
\end{abstract}

As this passage shows, Eva's perspective of motherhood is about enduring the hardships for her children; she does not have time for playing, for she is too busy trying to survive. Consequently, Eva's children grow stealthily under her "distant eye, and prey to her idiosyncrasies" (Morrison, Sula 41). Cassandra Fetters also suggests that Eva's detachment from her children results in emotional deprivation, for they are "starved for the needed recognition by their mother" (Morrison, Sula 36). Such a detachment is also perceived in Hannah and Sula's relationship, and is confirmed by Hannah's remark of not liking Sula (Morrison, Sula 57).

Eva's complexity goes beyond her sometimes misread motherly love. Her name suggests that she is "the mother of all living", as Joan Relke remarks in "The Archetypal Female in Mythology and Religion." In this sense, she grants life and takes it away (Christian 32). Just as she saves her son Plum when he was little, by shoving "the last bit of food she had in the world" (Morrison, Sula 34) up his buttocks and easing his pain, she kills him when he becomes an adult. When he comes back from war addicted to heroin, with no life prospects, she goes to his bedroom one night, rocks him like a baby, only to set him on fire afterwards. To explain why she killed Plum, she says he wanted to be a baby again and return to her womb: “after all that carryin' on, just gettin' him out 
and keepin' him alive, he wanted to crawl back in my womb and well... I ain't got the room no more even if he could do it" (Morrison, Sula 71).

This metaphor implies that Plum had not grown up. War had been such a traumatic experience for him that he could not bear talking about it: "everybody welcomed him and gave him a warm room next to Tar Baby's and waited for him to tell them whatever it was he wanted them to know. They waited in vain" (Morrison, Sula 45). Like Shaddrax, Plum is in shock due to his terrible experience with in war. Going back to Medallion does not make things easier because nothing would ever be the same. He becomes, then, a man-child, incapable of moving on with his life because he cannot be a man either outside or inside his home. Therefore, Eva kills him so he can die as a man, "not all scrunched up inside [her] womb, but like a man" (Morrison, Sula 72). In a sense, Eva's killing is an act of mercy, which makes him find peace and keeps "him from descending further into the stupor of drugs" (Dixon 103). According to Carl Gustav Jung, men need to overcome their Oedipus complex and become independent of their mothers in order to achieve maturity (ctd. in Relke, n.p.). Because Plum is unable to do so, Eva feels obliged to kill him so he would become a man: "I done everything I could to make him leave me and be a man but he wouldn't and I had to keep him out" (Morrison, Sula 72). Her killing ends his dependence on her, as well as her dependence on him.

Not so different from Eva is Nel's mother, Helene Wright, who, as her name suggests, is a righteous woman who loved "her house and enjoyed manipulating her daughter and her husband"; to the community, she is an "impressive woman..." conservative, willing to fight "social battles with presence and a conviction of the legitimacy of her authority" (Morrison, Sula 18). In the meantime, Eva Peace, Sula's grandmother, is "the creator and sovereign" of their enormous and very confusing house. She sits in "a wagon on the third floor directing the lives of her children, friends, strays, and a constant stream of boarders" (Morrison, Sula 30). Even though adults, out of respect, have to look down to talk to her - due to the very low wagon in which she wheels around the house - they have the feeling that "they were looking up at her, up into the open distances of her eyes, up into the soft black of her nostrils and up at the crest of her chin" (Morrison, Sula 31). However, if on the one hand Eva is a distant mother, on the other, Helene suffocates her daughter with her constant presence.

While Eva Peace "resists the patriarchal script of motherhood that demands women to mother children in a nuclear family in which the mother is subservient/ inferior to the husband" (O'Reilly 81), Helene Wright's conservativism helps to maintain women's traditional roles in any patriarchal society. She perceives her child's marriage, for example, as the "culmination of all she had been, thought or done in this world" (Morrison, Sula 79); she feels she has fulfilled her role in society she has raised a girl so well that she is getting married - and good girls get married.

Contradictorily, Eva resists patriarchy by raising her children by herself and, at the same time, cultivating traditional ideas of women's roles in society:

She fussed interminably with the brides of the newlywed couples for not getting their men's supper ready on time; about how to launder shirts, press them, etc. "Yo' man be here direc'lin. Ain't it 'bout time you got busy?" "Aw, Miss Eva. It'll be ready. We just having spaghetti."

"Again?" Eva's eyebrows fluted up and the newlywed pressed her lips together in shame. (Morrison, Sula 42)

Furthermore, when Sula returns to Medallion, Eva thinks she should get married and have children, because "no woman got no business 'floatin' around without no man" (Morrison, Sula 92). She raises her children by herself, but not out of choice. A woman choosing to be alone is improper for Eva.

Eva Peace's and Helene Wright's conflicting images show the variety of attitudes and roles black women may play in their communities; they also show the plural ways black women raise their children. Hannah Peace, for instance, asks her mother if she had ever loved them as children, because she had just confessed to her friends that she loved Sula, but did not like her, because children are "different people" (57). Mothers 
"can't help loving [their] own child", Hannah's friend states (Morrison, Sula 57). However, O’Reilly puts it, "a mother may not like a child at a particular moment, or at a particular stage, or at all, whether because of differences in personality, lifestyle, beliefs, or values" (Morrison, Sula 59). Hannah's comment, in this sense, is an honest comment, and breaks the ideology that motherly love is either unconditional or inexistent.

In Brewster, Mattie Michael is one of the most important characters who assist in breaking ideologies concerning motherhood. Mattie starts her journey to Brewster thirty-one years before the time of the novel, when Butch Fuller - a cinnamon-red man - calls her attention at the porch of her parent's house back in Tennessee. Her father had "repeatedly warned her against" Butch Fuller because he found him a "nocount ditch hound, and no decent woman would be seen talkin' to him." Nevertheless, Mattie is caught by Butch's sense of humor and laughter, which is like "April sunset” for her (Naylor, Brewster 9). Basil, Mattie’s son, is the fruit of the one afternoon she and Butch spent together in Tennessee.

As she walks up the steps into her new home in Brewster Place, Mattie smells sugar cane, which takes her into a journey through her past up to the moment when she loses the house she had spent thirty years of her life to pay for. Mattie leaves her parents' home after getting pregnant with Basil, who becomes her only window to the past; she never thinks of Butch as a husband or a father for her child. In fact, she feels that Basil does not belong to Butch: "it belonged to something out there in the heat of an August day and the smell of sugar cane and mossy herbs" (Naylor, Brewster 22). It belongs to a feeling of freedom and desire; nothing she could explain to her father or even to herself.

That is probably one of the reasons why she moves out of her house. Partially due to her father's violent treatment towards her, when she refuses to tell him her baby's father's name - but mostly because she wants to break free from her perfect-daughter role in a strict patriarchal family: "she just wanted to lay her head on the cushioned seat and suspend time, pretend that she had been born that very moment" (Naylor, Brewster 25). The only reminder of that past is her child: he brings back memories of the heat, the sugar cane and the smell of herbs, which is why she names him Basil.

Mattie decides to raise her child by herself, but it is misleading to think that she does so because she believes she is a superwoman, as the matriarch controlling image implies. Although Mattie stands as an important figure in the community of Brewster, Naylor seems to subvert this controlling image in many ways. Her name does allude to "an incarnation of the Mat(tie) riarch deplored by Moyniham," but it is reshaped so as to do justice to black single mothers (Fraser 98). Her story shows the struggles single black mothers - who are usually stereotyped as matriarchs - endure in their lives for the sake of their children.

Moreover, Naylor portrays, for instance, how stressful and painful it is for Mattie to leave her child at the care of a stranger while she is at work. She works six days a week, and "hardly ever saw the baby... It was heartbreaking when she missed his first step, and she had cried for two hours when she first heard him call Mrs. Prell 'Mama"' (Naylor, Brewster 28). Mattie truly resents having to stay away from her child, but there is no other option for her, once she is a single mother and has to provide for her son.

Another way Naylor subverts the matriarch controlling image is by showing how Mattie is overprotective towards Basil. For instance, when a rat bites his mouth in the boarding house they live in North Carolina, she quickly packs her bags, takes the baby in her arms, and roams aimlessly looking for another place to live, for she feels "she could never take him back to the place that had caused him so much pain" (31). For having to stay so much time apart from Basil while working, Mattie becomes quite attached to him; she insists in sleeping in the same bed with him, under the pretense that Basil is afraid of the dark.

Consequently, Basil grows up to be a seductive and irresponsible man and Mattie pats him on the shoulder:

Irresponsible, his counselors had said in school. High-natured, she had replied in her heart. Hadn't he said that they were always picking on him; everyone had been against him, except 
her. She had been the refuge when he ran from school to school, job to job. (Naylor, Brewster 43)

Mattie's overindulgence towards Basil encourages his irresponsibility, thereby creating a man-child, "a little boy who would always need her" (52); a conflict avoider, Mattie tries hard not to get into discussions with him. Unfortunately, though, she ignores Basil's wrongdoings and ends up paying a high price for it.

Another single mother is Lucielia Louise Turner or Ciel. When it comes to children's protection, Mattie and Ciel are quite similar to one another. Like Mattie, who did everything she could to avoid upsetting Basil, Ciel is "terribly possessive of Serena... refuses to leave her alone, even with Eugene" (Naylor, Brewster 96); she carries the girl everywhere, and is extra cautious of things that can hurt her; not surprisingly, Ciel is in shock after Serena's death. Serena meant the world to Ciel; she was "the only thing [she had] ever loved without pain" (Naylor, Brewster 93). After the funeral of the child, Mattie helps Ciel deal with her pain:

Mattie rocked her out of that bed, out of that room, into a blue vastness just underneath the sun and above time... She rocked her on and on, past Dachau, where soul-gutted Jewish mothers swept their children's entrails off laboratory floors. And she rocked on. She rocked her into her childhood and let her see murdered dreams. And she rocked her back, back into the womb, to the nadir of her hurt, and found it - a slight silver splinter, embedded just below the surface of the skin. And Mattie rocked and pulled and splinter gave way, but its roots were deep, gigantic, ragged, and they tore up flesh with bits of fat and muscle tissue clinging to them. They left a huge hole, which was already starting to pus over, but Mattie was satisfied. It would heal. (Naylor, Brewster 103-4)

This ritual of spiritual healing is the reason why Gloria Naylor refers to Mattie as an Earth Mother, while discussing the origins of the rocking scene in Brewster Place:

... The work began with that rocking scene. And I had written that as sort of a catharsis for myself. I was going through what I considered as being a great deal of pain. And I imagined a woman who would be feeling pain that intensely but for other reasons. And I sat down and wrote that. And what I had hoped for was a kind of earth mother to just knock down this door and come sit here on this couch and just rock. I wanted to be rocked out of my pain. And that's how I invented Mattie Michael in that scene. (Naylor, An Interview 55)

Naylor also comments, in another interview, that Mamma Day is "an earth-mother figure to her niece, Cocoa, a New Yorker" (Naylor, Gloria Naylor 72). Such an image of the earth-mother is repeated in many interviews Naylor gives, and it possibly refers to a "healer of the soul, someone who helps other people to overcome unbearable mental but also physical pain" (Procházková 11).

In mythology, the earth mother image appears in different cultures; according to Joan Relke, they can be "Inana, Durga, Cybele, and Sekhmet, goddesses of ancient Mesopotamia, India, Anatolia, and Egypt" (n.p). They are often represented as a paradox in society: as an example, they may be loving, nurturing, and protective on one hand, and fierce, destructive and violent on the other; they are, in some sense, related to nature, which can either give or take life away. Eva Peace, as mentioned previously, is a mother figure of sorts, since she has a strong connection with nature - which often gives her signs to interpret the future. Moreover, she may be considered an earth mother also when she takes her own son's life. The same may be said about Mattie Michael, who is able to heal Ciel in a moment of great pain. Mattie's rocking and bathing causes Ciel to heal probably because: firstly, Mattie loves Ciel as her own child, once she has known Ciel since she was a toddler, and has loved Ciel's grandmother, Eva Turner, like a mother; secondly, because Mattie also knows how it feels to lose a child, and, therefore, can understand Ciel's pain and help her heal.

\section{Conclusion}

In an analysis o Lena and Pilate, characters in $A$ Raisin in the Sun and Song of Solomon respectively, Natalia F. Oliveira and Michelle Medeiros remark: 
[Lena and Pilate] challenge stereotypes associated with black women as the authoritative matriarch ... and the careless pariah. They worry about their families, even when their actions are unorthodox. In their own ways, they are both a progressive force, courageous spirits that inspire and help their family move forward without forgetting their past. (161)

It is fair to state that the characters examined here have a similar purpose. Controlling images such as the matriarch - popularized especially in the social media and entertainment industry - besides causing psychological damage on a whole segment of the population, unveil in different ways the mechanisms of a white, racist, patriarchal system which, to remain in power, blames black women for the social ills resulting from policies of exclusion and segregation. Documents such as Daniel Moynihan's report have only contributed to perpetuate hate against black women who, throughout history, have faced all sorts of obstacles to raise their families and deal with racism and exclusion. Morrison's and Naylor's novels provide alternative portraits of black families, women, men and the different ways they deal with their dilemmas. Black women such as Eva, Ciel, Mattie, among others, may be overly assertive and hard-headed at times, but they can hardly be blamed for being the sole source of the social problems afflicting their families and communities.

\section{Note}

1. Morrison, 69

\section{References}

Christian, Barbara. "The Contemporary Fables of Toni Morrison." Toni Morrison's Sula. Modern Critical Interpretations. Harold Bloom, Ed. Philadelphia: Chelsea House, 1999. 233-45. Print.

Collins, Patricia Hill. Black Feminist Thought: Knowledge, Consciousness, and the Politics of Empowerment. 2nd ed. New York: Routledge, 2000. Print.

Dixon, Melvin. "Like an Eagle in the Air: Toni Morrison." Toni Morrison's Sula. Philadelphia: Chelsea House, 1999. 93-104. Print. Modern Critical Interpretations.
Fraser, Celeste. "B(l)ack Voices: The Myth of the Black Matriarchy and The Women of Brewster Place." Gloria Naylor: Critical Perspectives Past and Present. Edited by Henry Louis Gates and K.A. Appiah. New York: Amistad,1993. 90-105. Print.

Fetters, Cassandra. "The Continual Search for Sisterhood: Narcissism, Projection, and Intersubjective Disruptions in Toni Morrison's Sula and Feminist Communities." Meridians 13.2 (2016): 28. Web 11 Oct. 2016.

Gilman, Sander L. "Black Bodies, White Bodies: Toward an Iconography of Female Sexuality in Late NineteenthCentury Art, Medicine, and Literature." Race, Writing, and Difference. Ed. Henry Louis Gates, Jr. Chicago and London: University of Chicago Press, 1985. 223-61. Print.

Hooks, bell. We Real Cool: Black Men and Masculinity. New York: Routledge, 2004. Print.

Morrison, Toni. Sula. London: Picador, 1991. Print.

Mowatt, Rasul, and Bryanna French. "Black/Female/Body Hypervisibility and Invisibility: A Black Feminist Augmentation of Feminist Leisure Research." Journal Leisure Research 45.5 (2013): 644-56. Web. 14 Aug. 2014.

Moyniham, Daniel. United States Dept. of Labor. Office of Policy Planning and Research. The Negro Family: The Case for National Action. Washington D.C., 1965. PDF File.

Naylor, Gloria. "An Interview with Gloria Naylor." Interview by Kay Bonetti. Conversations with Gloria Naylor. Ed. Maxine L. Montgomery. Jackson: U of Mississippi, 2004. 39-54. Print

"Gloria Naylor." Interview by Pearlman Mickey and Katherine Usher Henderson. Conversations with Gloria Naylor. Ed. Maxine L. Montgomery. Jackson: U of Mississippi, 2004. 70-75. Print

The Women of Brewster Place. New York: Penguin, 1998. Print.

Nigro, Marie. "In Search of Self: Frustration and Denial in Toni Morrison's Sula." Journal of Black Studies 28.6 (1998): 724-737.

Oliveira, Natalia F., M. Medeiros. "Is It All About Money? Women Characters and Family Bonds in Lorraine Hansberry's A Raisin in the Sun and Toni Morrison's Song of Solomon." Revista Scripta Uniandrade 13.2 (2015): 151-63. Web. 11 Oct. 2016.

O'Reilly, Andrea. Toni Morrison and Motherhood: A Politics of the Heart. Albany: State University of New York, 2004. Print. 
Procházková, Lucy. "Motherhood and Sisterhood in Gloria Naylor's Novels." M.A. Thesis. Masaryk University, 2012. Print.

Relke, Joan. "The Archetypal Female in Mythology and Religion: The Anima and the Mother of the Earth and Sky." Europe's Journal of Psychology [Online], 3.2 (2007): n. p. Web. 13 Sep. 2015.

Sewell, Christopher J. “Mammies and Matriarchs: Tracing Images of the Black Female in Popular Culture 1950s to Present." Journal of African American Studies 17 (2013): 308-26. PDF File.

Walker, Alice. In Search of Our Mothers' Gardens: Womanist Prose. San Diego: Harcourt Brace Jovanovich, 1983. Print.

West, C. "Mammy, Jezebel, and Sapphire: Developing an 'oppositional Gaze' toward Images of Black Women." Lectures on the Psychology of Women. Ed. J. Chrisler, C. Golden, and P. Rozee. New York: McGraw-Hill, 2004. 286-99. Print.

Recebido em: 12/07/2016

Aceito em: 21/10/2016 